\title{
Yield and Physiological Response of Potatoes Indicate Different Strategies to Cope with Drought Stress and Nitrogen Fertilization
}

\author{
David Saravia $^{1}$ - Evelyn Roxana Farfán-Vignolo ${ }^{1}$ - Raymundo Gutiérrez ${ }^{1}$. \\ Felipe De Mendiburu ${ }^{1} \cdot$ Roland Schafleitner $^{2} \cdot$ Merideth Bonierbale $^{1} \cdot$ M. Awais Khan ${ }^{1}$
}

Published online: 25 March 2016

(C) The Author(s) 2016. This article is published with open access at Springerlink.com

\begin{abstract}
Access to Water and Nitrogen $(\mathrm{N})$ are key challenges in potato crop management that could be optimized through understanding related agronomic and physiological traits. The responses to water deficit and two levels of nitrogen ( 0 and $200 \mathrm{~kg}$ N.ha-1) were assessed here for agronomic and physiological traits for potato genotypes UNICA, AchiranaINTA, and CIP397077.16, chosen for their short vegetative period (90-110 days) and tolerance to water deficit. Nitrogen Use Efficiency (NUE) was greatly reduced in all genotypes under drought, even dropping to nearly zero. Despite this, the tuber yield and total biomass reduction of around $50 \%$ for all genotypes could be alleviated with $\mathrm{N}$ application. Normalized Difference Vegetation Index (NDVI), chlorophyll content (SPAD), and Canopy cover (CC) were found to be good indicators for predicting nitrogen deficits and detecting early stress by drought. Overall, each genotype had different strategies to manage $\mathrm{N}$ and cope with drought stress. UNICA was the most efficient genotype at using the $\mathrm{N}$ present in the soil and tolerating drought stress, while Achirana-INTA was most affected by drought in terms of NUE. Based on the results, it is suggested that maximum fertilizer use efficiency can be
\end{abstract}

David Saravia and Evelyn Roxana Farfán-Vignolo are equally contributed authors.

Electronic supplementary material The online version of this article (doi:10.1007/s12230-016-9505-9) contains supplementary material, which is available to authorized users.

M. Awais Khan

awais.khan@cgiar.org

1 International Potato Center (CIP), Av. La Molina, $1895 \mathrm{La}$ Molina, Lima, Perú

2 The World Vegetable Center (AVRDC), 60 Yi-min Liao Shanhua, Tainan 74151, Taiwan obtained with low $\mathrm{N}$ rates applied under well-watered conditions. Improved NUE and a greater understanding of the physiological response of crops to drought stress and $\mathrm{N}$ fertilization will help to reduce fertilizer use, lessening the effects of water contamination and improving input efficiency.

Resumen El acceso al agua y al nitrógeno $(\mathrm{N})$ son retos clave en el manejo del cultivo de la papa, que pudieran optimizarse a través del entendimiento de aspectos agronómicos y fisiológicos relacionados. Aquí se analizaron las respuestas al déficit de agua y a dos niveles de nitrógeno $(0 \mathrm{y}$ $200 \mathrm{~kg} \mathrm{~N} \mathrm{ha}^{-1}$ ) para rasgos agronómicos y fisiológicos para los genotipos de papa UNICA, Achirana-INTA y CIP397077.16, seleccionados por su período vegetativo corto (90-110 días) y su tolerancia al déficit de agua. La eficiencia en el uso del nitrógeno (NUE) se redujo grandemente en todos los genotipos bajo sequía, aun bajando a cerca de cero. A pesar de esto, el rendimiento de tubérculo y la reducción total de biomasa de cerca del $50 \%$ para todos los genotipos pudo superarse con la aplicación de N. Se encontró que el Índice de la Diferencia Normalizada de Vegetación (NDVI), el contenido de clorofila (SPAD) y la cubierta del follaje (CC), fueron buenos indicadores para la predicción de los déficits de nitrógeno y para detectar agobio temprano por sequía. Sobre todo, cada genotipo tuvo diferentes estrategias para manejar el $\mathrm{N}$ y lidiar con el agobio hídrico. UNICA fue el genotipo más eficiente en el uso del $\mathrm{N}$ presente en el suelo y en la tolerancia al estrés por sequía, mientras que Achirana-INTA fue el más afectado por sequía en términos de NUE. Con base en los resultados, se sugiere que la máxima eficiencia en el uso de fertilizante se puede obtener con niveles bajos de $\mathrm{N}$ aplicados en condiciones de buena hidratación. El mejoramiento en la NUE y un mayor entendimiento de la respuesta fisiológica de los cultivos al agobio por sequía y la fertilización nitrogenada, ayudarán a reducir el uso de fertilizantes, disminuyendo los 
efectos de la contaminación del agua y mejorando la eficiencia de los insumos.

Keywords Drought tolerance index · Nitrogen use efficiency · Reflectance - NDVI - Canopy cover - Chlorophyll content SPAD

\section{Introduction}

Potato is the most important non-grain food crop in the world (FAO 2011). However, its productivity is limited by degradation of soil root zone and the consequences of climate change such as drought and heat (IPCC 2007). Potato depends on a regular supply of water and nitrogen $(\mathrm{N})$ to ensure high quality yield performance (Bélanger et al. 2001, Levy et al. 2013). The shallow root system of modern potato varieties frequently results in a high rate of nitrate leaching and consequently to ground water pollution (Levallois et al. 1998). Shallow roots also make the plant susceptible to drought stress leading to decreases of tuber yield and quality, or, in severe cases, even to total loss of the harvest (Devaux et al. 2010).

Water stress in the plant leads to stomatal closure, reduction of transpiration and water transport through the plant. Reduced water uptake also decreases the nutrient absorption rate (He and Dijkstra 2014). Drought conditions also affect nutrient transport to the root surface by inducing root shrinkage and subsequent loss of the soil-root contact (Ahmad et al. 2013). Nitrogen plays important role in plant development e.g., it increases leaf expansion, and photosynthesis ratio per unit area. However, $\mathrm{N}$ applied in agriculture can be lost and could become potential pollutant instead. $\mathrm{N}$ use efficiency (NUE) is the ratio between the amount of fertilizer $\mathrm{N}$ removed from the field by the crop and the amount of fertilizer $\mathrm{N}$ applied. Each step of plant NUE including N uptake, transport, assimilation, and remobilization is regulated by both genetic and environmental factors (reviewed by Xu et al. 2012). The interaction between, genotype, amount of nitrogen, moisture level and soil type define NUE. Genetic variations in NUE have been identified for a number of crop species like maize, pearl millet, wheat and potato (Payne et al. 1995, Costa et al. 1997). Good absorption and utilization of $\mathrm{N}$ improves the efficiency and cost effectiveness of fertilizers, and prevent losses of nutrients to ecosystems and enhance crop yields (Baligar et al. 2001).

Imbalance between water supply and nitrogen fertilization reduces NUE. A balanced $\mathrm{N}$ status in the plant can alleviate the effects of drought stress by preventing cell membrane damage and enhancing osmoregulation. Nitrogen application minimizes the adverse effect of drought on dry matter and grain yield in pearl millet by increasing nutrient concentration in stems, live leaves, and dead leaves (Ashraf et al. 2001). Also, yield of barley, wheat and maize in drylands increases with enhanced N supply (Raun and Johnson 1999). In addition, sufficient $\mathrm{N}$ nutrition resulted in higher water use efficiency (WUE), as most of the leaf $\mathrm{N}$ is used to synthesize components of the photosynthetic apparatus, in particular RuBisCo, thus playing a major role in carbon assimilation (Costa et al. 1997). Nevertheless, high doses of applied $\mathrm{N}$ under mild water deficit, proved to be detrimental to winter wheat (Payne et al. 1995).

The overall efficiency of applied $\mathrm{N}$ fertilizers has been reported to be about or lower than $50 \%$ (Baligar et al. 2001). Obtaining genotypes with satisfactory yield under low $\mathrm{N}$ fertilization is one of the most difficult challenges for breeders. More data on interactions between plant traits with external factors, especially information on key traits leading to a better adaptation of crop plants to N-depleted soils, especially under water-limiting conditions are required to improve the genetics of NUE (Olesen et al. 2011, Piao et al. 2010). Physiological parameters such as canopy cover (CC), chlorophyll content (SPAD), and the Normalized Difference Vegetation Index (NDVI), among others, are related with $\mathrm{N}$ nutrition and have been reported to indicate plant fitness under stress and could be useful indicators for selection of superior genotypes in breeding and genetic improvement programs aiming to enhance stress tolerance (Anithakumari et al. 2012, Cabello et al. 2013).

This study aimed to assess the response to water deficit and two levels of nitrogen ( 0 and $200 \mathrm{~kg}$ N.ha-1) on agronomic and physiological traits of three potato clones (UNICA, Achirana-INTA, and CIP397077.16) chosen for their short vegetative period (90-110 days) and relative drought tolerance.

\section{Materials and Methods}

\section{Plant Material and Experimental Design}

Three potato genotypes; UNICA (CIP392797.22), AchiranaINTA (CIP720088) and CIP397077.16, known for their earliness and drought tolerance (Schafleitner et al. 2007), were grown from mid-February to June 2010 in ridges in native soil in a rain out shelter at the International Potato Center (CIP) in Huancayo (3289 m above sea level). Plants were grown in a randomized complete block design (RCBD) with two rows of 10 plants each and 3 replications, with $0.9 \mathrm{~m}$ space between rows and $0.3 \mathrm{~m}$ space between plants.

Soil samples were randomly taken at $30 \mathrm{~cm}$ depth (see section $3 \mathrm{~b}$ ) along a zigzag pattern over time to test the available nitrate in the soil across at different developmental stages of the plants. The samples were analyzed at Soil Testing Laboratory at the Universidad Agraria La Molina, LimaPeru. According to the soil analysis, soils were loamy Entisol ( $46 \%$ sand, $34 \%$ lime, $20 \%$ clay) with a bulk density 
of $1.45 \mathrm{~g} \mathrm{~cm}^{-3}$, wilting point $13.7 \%$ (Vol.), field capacity $26.8 \%$ (Vol.), saturation $45.3 \%$ (Vol.), pH 5.2, C.E (Electrical Conductivity) $0.45 \mathrm{dS} / \mathrm{m}$ and $2.3 \%$ of soil organic content. During the growing season (March-June), weather data was collected using a weather station model U30 HOBO (Onset Corporation, Bourne, MA, USA). On average, photosynthetically active radiation (PAR) was $414.9 \pm 105.8$ $\mu \mathrm{E}$, relative humidity $(\mathrm{RH})$ was $65.2 \pm 9.7 \%$, and $\mathrm{max} / \mathrm{min}$ temperatures were $24.1 \pm 5.3 / 5.8 \pm 2.3{ }^{\circ} \mathrm{C}$ during the growing season (Fig. 1).

\section{Stress Treatments}

Two levels of nitrogen fertilization ( 0 and $\left.200 \mathrm{~kg} \mathrm{~N} \cdot \mathrm{ha}^{-1}\right)$ and two irrigation treatments $(\mathrm{WW}=$ well-watered, $\mathrm{D}=$ drought $)$

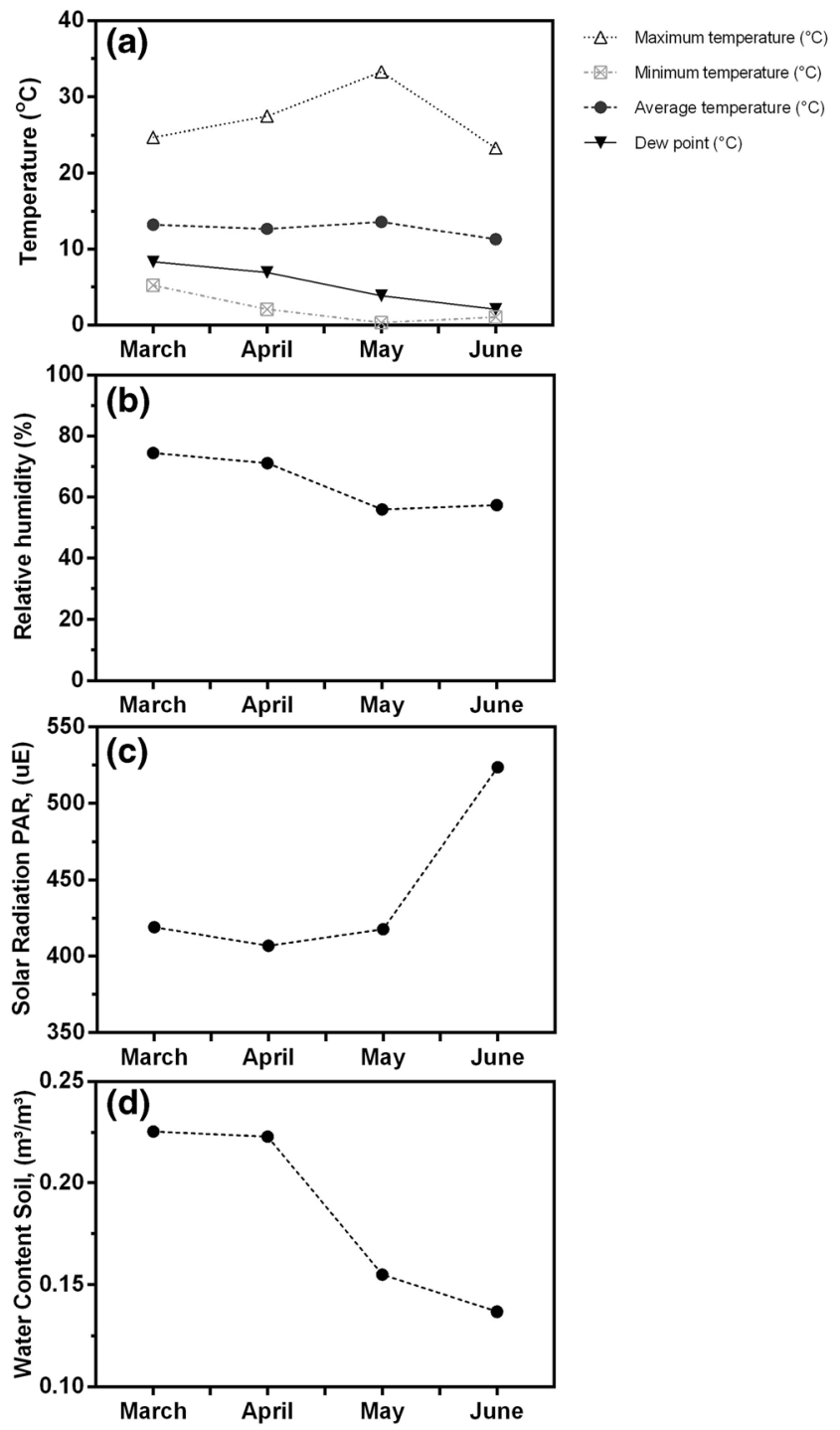

Fig. 1 Weather data recorded over the growing period of the experiment (March-July). (a) Temperatures in ${ }^{\circ} \mathrm{C}$, minimum, maximum, average, and dew point, (b) Relative humidity (\%), (c) Solar radiation/PAR in $\mu \mathrm{E}$, (d) Soil water content in drought conditions in $\mathrm{m}^{3} / \mathrm{m}^{3}$ using flooding irrigation were applied. Soil moisture level was measured with an irrometer and maintained at approximately $0.2 \mathrm{~m}^{3} / \mathrm{m}^{3}$ in the W treatment and in D until initiation of the treatment. Terminal drought treatment was initiated at 60 days after planting (DAP), by complete suspension of irrigation water at about mid-April, corresponding to tuber initiation in tropical highlands for the clones used in the experiment. $\mathrm{N}$ fertilization (200 kg N.ha-1 from a mixture of ammonium phosphate, ammonium nitrate, and potassium chloride) was applied for each plant and was done twice, once at planting and the other at hilling (45 DAP). Other nutrients $\mathrm{P}, \mathrm{K}$ and micronutrients were applied in recommended doses. Before the start of the experiment, maize was planted in the field without fertilizing to decrease residual nitrate in the soil.

\section{Trait Evaluation}

\section{Biomass and Drought Tolerance Index}

Harvest was carried out at 110 DAP, tuber fresh weight (g) was determined in the field and dry weight $(\mathrm{g})$ of the other components (leaf, stem, and root) and tubers was determined after drying in a forced air oven at $80^{\circ} \mathrm{C}$ for three days. Yield $\left(\mathrm{g} \mathrm{DW}\right.$.plant ${ }^{-1}$ ) and total dry weight biomass (g DW.plant ${ }^{-1}$ ) were calculated for all components (leaf, stem, and root) and used to calculate harvest index ( $\mathrm{HI}=$ tuber dry weight/(tuber dry weight + leaf and stem biomass dry weight)), and the drought tolerance index $(\mathrm{DTI}=(($ yield under stress $\mathrm{x}$ yield under control)/mean yield under control) (Cabello et al. 2013). A genotype with high DTI and high yield is considered tolerant.

\section{Nitrogen Use efficiency (NUE) and residual nitrate}

NUE was calculated by dividing the yield $(\mathrm{kg})$ with the $\mathrm{N}(\mathrm{kg})$ applied plus residual nitrate in the soil (Payne et al. 1995). Residual nitrate was determined by analyzing the concentra-

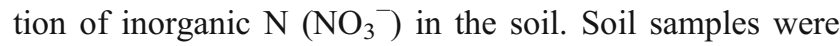
collected at $30 \mathrm{~cm}$ depth, with a punch at the lateral side of the plant at $0,53,83$, and 104 DAP. To determine nitrogen content, fresh soil was extracted with $0.34 \mathrm{M}$ potassium sulfate, and after filtering, analyzed colorimetrically with the addition of salicylic acid, sulfuric acid, and sodium hydroxide. NO3-N was detected with a spectrophotometer at $410 \mathrm{~nm}$, following the method described in Ayre and Roman (1992).

\section{Canopy Cover and Reflectance}

Canopy cover (\%) was determined at $52,61,67,74,89$, and 97 DAP using a grid of $90 \mathrm{~cm} \times 90 \mathrm{~cm}$. Measurements were made using the three central plants of each row and for each experimental unit. Reflectance, or the Normalized Difference Vegetation Index (NDVI), 
was taken at $51,61,68,75,82,89$, and 97 DAP using a reflectometer SpectroSense2+ (Skye Instruments Inc., Llandrindod Wells, UK) using two types of wavelengths (red and infrared). NDVI was calculated following the formula:

$\mathrm{NDVI}=(\rho \mathrm{NIR}-\rho \mathrm{Red}) /(\rho \mathrm{NIR}+\rho \mathrm{Red})$

\section{Chlorophyll content (SPAD units) and leaf area (LA)}

Chlorophyll content was determined at 51, 67, 84, and 97 DAP using a portable chlorophyll meter (Minolta SPAD502, Konica Minolta, Sakai, Osaka, Japan), at three positions (upper, middle, and lower parts) of the youngest fully expanded leaf (third from the apical part), and averaged to represent individual measurement of a leaf ( $\mathrm{Li}$ et al. 2012). Leaf area (LA) was determined in two plants harvested in each experimental unit at 76 and 91 DAP. All leaves of the plant were placed in a transparent plastic cover and scanned and total leaf area was determined using Compu Eye, Leaf \& Symptom Area software (Bakr, 2005).

\section{Statistical Analysis}

Statistical analysis was performed in SAS (v.9.2; SAS Institute, Inc., Cary, North Carolina) using a combined analysis of four variables (two irrigation treatments and two nitrogen fertilizations) and four replications in a randomized complete block. Figures and correlation analysis were done in Graphpad (v.5, San Diego, CA). Analysis of variance (ANOVA) was performed to describe the genotype and the treatment effects.

\section{Results}

\section{Agronomic Traits}

Drought significantly reduced yield and total biomass $(p<0.01$ and $p<0.001)$ (Fig. 2a and 2c). This reduction was higher than $50 \%$ in comparison to well-watered (WW) plants; however, $\mathrm{N}$ application alleviated this reduction by almost doubling yield, except for Achirana-INTA. CIP397077.16 and UNICA had similar responses to drought in terms of yield and total biomass. In both cases, the reduction was less when $\mathrm{N}$ was present (Fig. $2 \mathrm{a}$ and $2 \mathrm{c}$ ). Harvest index (HI) (Fig. 2b) had a similar trend for UNICA and CIP397077.16. N application generally reduced HI in both treatments (drought (D) and well-watered (WW). AchiranaINTA had the lowest HI under drought and when N was present (D200 kg N.ha-1). N application increased the tolerance as defined by the drought tolerance index (DTI) in all genotypes

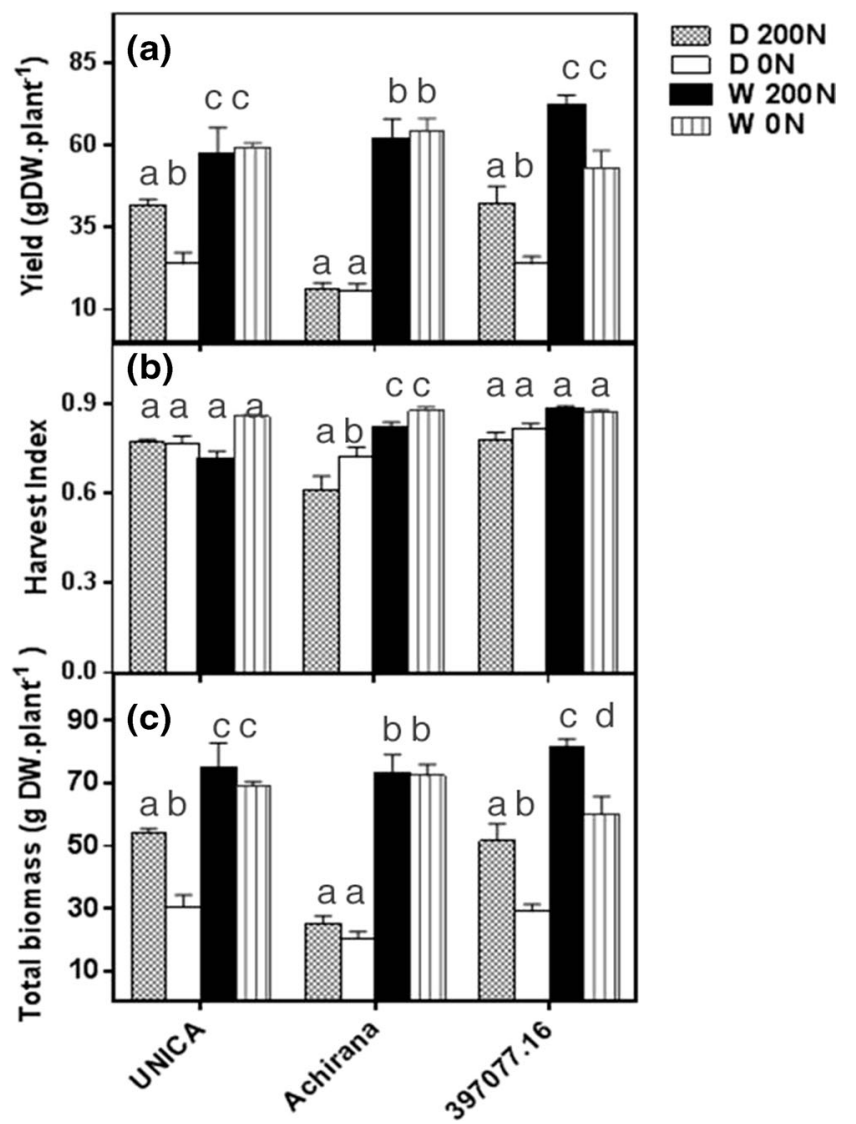

Fig. 2 Tuber yield (a), Harvest index (b) and Total Biomass (dry weight) (c) of three genotypes (UNICA, Achirana, and 307,077.16) under drought treatments and two levels of nitrogen (D200 kg N.ha1 = Drought with $200 \mathrm{~kg} / \mathrm{ha}$ of $\mathrm{N}, \mathrm{D} 0 \mathrm{~N}=$ Drought with $0 \mathrm{~kg} / \mathrm{ha}$ of $\mathrm{N}$, W200 kg N.ha-1 = Well-watered plants with $200 \mathrm{~kg} / \mathrm{ha}$ of N, and $\mathrm{W} 0 \mathrm{~N}=$ well-watered with $0 \mathrm{~kg} / \mathrm{ha}$ of $\mathrm{N}$ ). Data are means $\pm \mathrm{SE}$

except Achirana-INTA, which had the lowest DTI in both treatments (Fig. 3a). This genotype behaved similarly with or without extra N. Nitrogen use efficiency (NUE) in all genotypes was much higher when no extra $\mathrm{N}$ was applied (W0N and D0N) (Fig. 3b). Achirana-INTA had the highest NUE under WW conditions.

Maximum day temperature during early growth and tuber initiation were around $20-25^{\circ} \mathrm{C}$, and then increased to $37^{\circ} \mathrm{C}$ by about 75 DAP, after which regular spikes to the mid-30s were present until harvest (Fig. 1). Solar radiation was constant until harvest time, when it rapidly increased. Soil moisture levels in the drought treatment were reduced by more than half after drought initiation, from 0.22 to $0.13 \mathrm{~m}^{3} / \mathrm{m}^{3}$, while relative humidity in the air remained close to constant (Fig. 1). The reduction in moisture level was sharp from March to April $\left(0.22\right.$ to $\left.0.15 \mathrm{~m}^{3} / \mathrm{m}^{3}\right)$ but slow from April to May $\left(0.15\right.$ to $\left.0.13 \mathrm{~m}^{3} / \mathrm{m}^{3}\right)$. At planting (0 DAP) all treatments and genotypes had similar levels $(\sim 6.07 \mathrm{ppm})$ of residual nitrate $\left(\mathrm{NO}_{3}{ }^{-}\right)$in the soil (data not shown). At 53 DAP there was an increase in the residual $\mathrm{NO}_{3}{ }^{-}$in all the genotypes in the treatments with extra N (W200 kg N.ha-1 and D200 kg N.ha-1). 


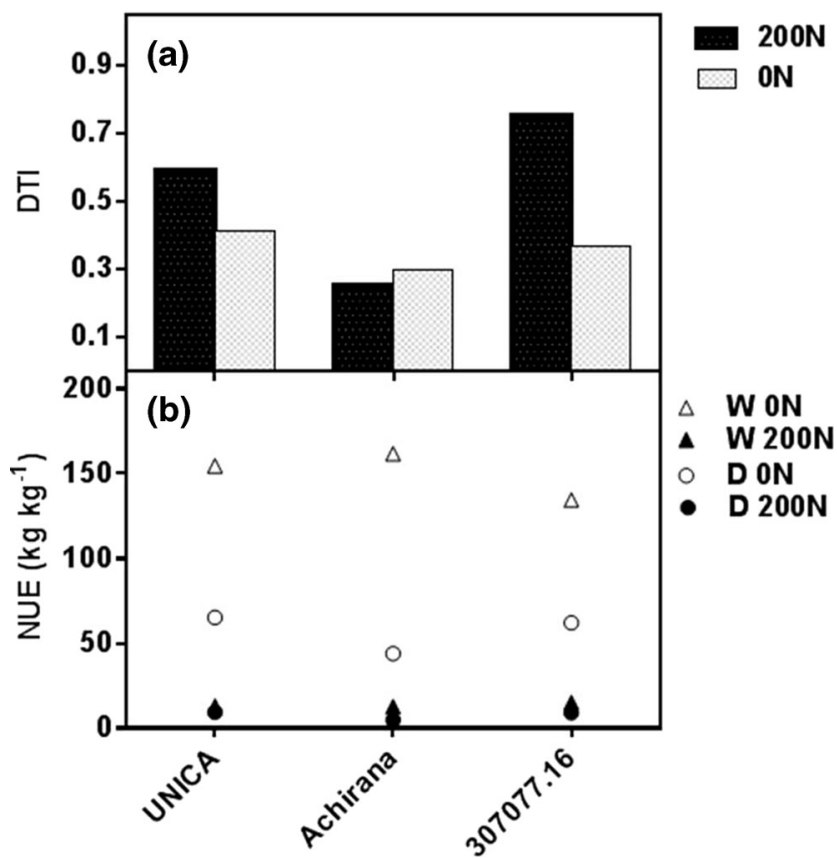

Fig. 3 Drought tolerance index (DTI) of tuber yield (a), and Nitrogen use efficiency (NUE) (b), of three genotypes (UNICA, Achirana-INTA, and CIP397077.16). $200 \mathrm{~kg} \mathrm{~N} \cdot \mathrm{ha}-1=200 \mathrm{~kg} / \mathrm{ha}$ of N, $0 \mathrm{~N}=$ No N application, D200 kg N.ha-1 = Drought with $200 \mathrm{~kg} / \mathrm{ha}$ of N, D0N = Drought with $0 \mathrm{~kg} / \mathrm{ha}$ of N, W200 kg N.ha-1 = Well-watered plants with $200 \mathrm{~kg} /$ ha of N and $\mathrm{W} 0 \mathrm{~N}=$ well-watered with $0 \mathrm{~kg} / \mathrm{ha}$ of $\mathrm{N}$ )

This increase was around $50 \%$ in the WW treatment and $10 \%$ in the drought treatment for both UNICA and Achirana-INTA, and $10 \%$ for both treatments for CIP397077.16. In the treatments that did not get extra N (W0N and D0N) the opposite happened, a decrease of around $50 \%$ in both treatments was noticed in all genotypes.

\section{Physiological Traits}

All physiological traits were evaluated at least three times after drought initiation. Canopy cover and NDVI of the plants varied greatly over the different time points (Fig. 4). Under well-watered conditions, the decline due to maturity and senescence of the plant canopy cover (CC) started at around 74DAP (Fig. 4a and $4 c)$. Under drought conditions, this decline was more pronounced with an average reduction of around $44 \%$. Achirana-INTA was the genotype most affected by drought, with reduction of over $57 \%$ of its initial CC. $\mathrm{N}$ application led to an increase in $\mathrm{CC}$ of about $21 \%$ in all the genotypes $(p<0.05$, Sup. Table 1$)$ that was more marked under drought conditions (Fig. $4 \mathrm{~b}$ and $4 d)$.

The Normalized Difference Vegetation Index (NDVI) has a similar pattern as $\mathrm{CC}$, with $\mathrm{R}^{2}=0.81$. The differences in the NDVI can be observed at different developmental stages. ANOVA revealed significant differences within irrigation treatments (I) in all the genotypes, i.e. the water status was mainly affected by drought and not by the additional $\mathrm{N}$ supply (Sup. Table 1 ) At 89DAP, significant interactions were found that were not present at previous stage (75DAP).

Leaf chlorophyll meters (SPAD-502), have been used in various crops as an indirect indicator of plant $\mathrm{N}$ status, often linked to the greenness and thickness of the leaves (Wu et al. 2007, Vos and Bom 1993). Figure 5 depicts chlorophyll content (as SPAD units) and leaf area of the three genotypes used in this experiment. SPAD results showed no significant differences among the different clones at 51 DAP (Sup. Table 1). Achirana-INTA had the highest SPAD value $(56.4 \pm 1.18)$ at W200 kg N.ha-1 treatment along all the time points measured. At 97DAP, significant positive correlation coefficients were found between SPAD and NDVI $(r=0.75, p=0.005)$, SPAD and CC $(r=0.69, p=0.013)$, and SPAD and LA $(r=0.60$, $p=0.041)$ (Sup. Table 2).

Variation due to $\mathrm{N}$ treatment was found as early as $67 \mathrm{DAP}$ $(p<0.001)$ and continued over further growth stages (Fig. 5a, $5 \mathrm{~b}, 5 \mathrm{c}$ and $5 \mathrm{~d}$ ), while variation due to drought treatment was also detected at 67 DAP, 7 days after drought initiation $(p<0.01)$, and was marked over all growth stages. At 74DAP, two weeks after drought initiation, drought and $\mathrm{N}$ deficiency led to significant differences in leaf area (LA) (Figure5e and 5f) $(p<0.001$ and $p<0.01)$. The reduction of LA was about 40 and $25 \%$ for drought and $\mathrm{N}$ treatment, respectively. Significant correlations among yield, canopy cover and NDVI, have been noticed in both time points measured (Sup. Table 2).

\section{Discussion}

Nitrogen Use Efficiency (NUE) was greatly reduced in all genotypes under drought with no added N. When additional $\mathrm{N}$ was given, NUE even dropped to nearly zero in drought exposed plants, and was also near zero in well-watered plants (Fig. 3), indicating that the plant is unable to make use of the available Nitrogen, to which the very low soil moisture probably Contributes. maximum temperatures greatly increased during tuber bulking, reaching up to $37{ }^{\circ} \mathrm{C}$, which could exacerbate the effects of drought. Usually there are two fundamental processes that define NUE: the ability of the plant to up take $\mathrm{N}$ from the soil, and the ability of the plant to utilize taken up $\mathrm{N}$ for plant organ development (Hirel et al. 2007). Efficiency of both processes depends on several abiotic and biotic factors. For example, it has been shown that heat stress can affect soil microbial activity, which could have an impact on Nitrogen use as well (Dell et al. 2012). 
Fig. 4 Canopy cover $(\mathbf{a}, \mathbf{b}, \mathbf{c}$, and d) and reflectance (NDVI) (e, f, g, and $\mathbf{h}$ ) in three potato genotypes (UNICA, Achirana-INTA, and CIP307077.16) under two irrigation treatments and two $\mathrm{N}$ levels (D200 kg N.ha-1 = Drought with $200 \mathrm{~kg} / \mathrm{ha}$ of N, D0N = Drought with $0 \mathrm{~kg} / \mathrm{ha}$ of N, W200 kg N.ha$1=$ Well-watered plants with $200 \mathrm{~kg} / \mathrm{ha}$ of N, and W0N = wellwatered with $0 \mathrm{~kg} / \mathrm{ha}$ of $\mathrm{N}$ ). Days after planting (DAP). Data are means $\pm \mathrm{SE}$

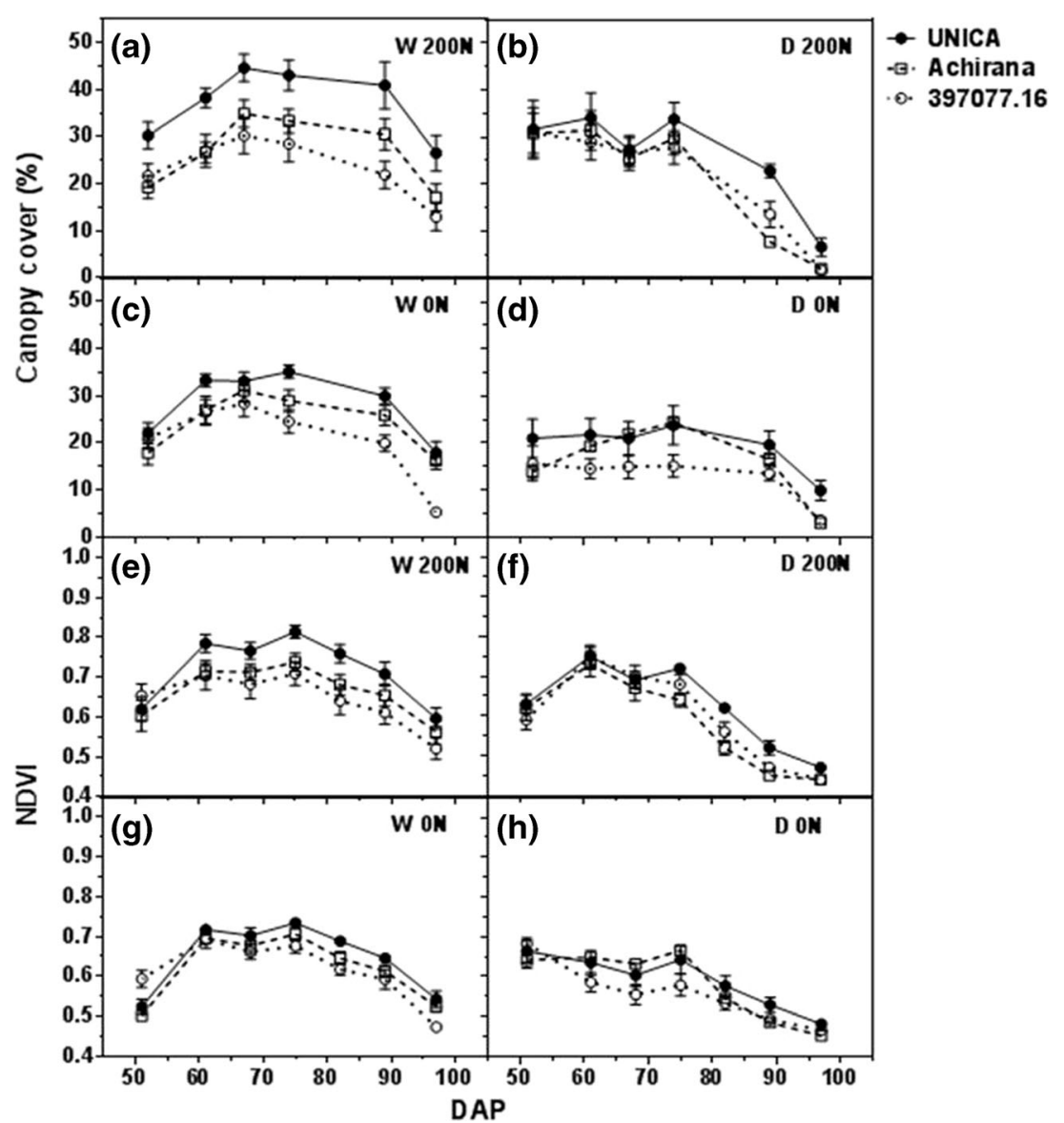

The additional fertilization of the plants on day 45 had no significant effect on yield under well-watered conditions, except in CIP397077.16. It is likely that by 45 DAP, tuber initiation is nearing or at completion, so the additional nitrogen cannot induce more tubers to initiate. At the same time, tuber bulking, still ongoing, may not be influenced by added nitrogen to a measurable degree. The overall effect of drought on plant NUE showed that maximum fertilizer use efficiency can be obtained with low $\mathrm{N}$ rates applied under well-watered conditions (Fig. 3b). Under drought conditions, plant growth gets depressed by reducing the uptake transport and redistribution of nutrients, and translocating more sugars to the tubers than to the above ground part before early senescence or maturity occurs (Deblonde and Ledent 2001), as was also seen in the reduction of tuber yield and total biomass (Fig. 2a and 1c) under water deficit of around $50 \%$ for all genotypes. The combination of water deficiency and no additional $\mathrm{N}$ was also detrimental to all the genotypes tested. $\mathrm{N}$ application had no effect on yield and biomass under well-watered conditions, however, under drought, both traits were increased for UNICA and CIP397077.16 (Fig. 2), indicating that high levels of $\mathrm{N}$ can be useful in drought conditions to overcome the greatly reduced NUE, even when it is possible that some of the protective effect may be from the $\mathrm{N}$ taken up by the plants in wet predrought conditions. These results are in agreement with previous results observed in pearl millet, barley, wheat, and maize, in which it was found that $\mathrm{N}$ application affects $\mathrm{C}$ partitioning, improves accumulation of soluble sugars built up in plant organs (stems and leaves), and increases anti-oxidative defense mechanisms to reduce photo-oxidation and early leaf senescence (Waraich et al. 2011, Ashraf et al. 2001, Raun and Johnson 1999). However, as the benefit of additional $N$ was not evident for all genotypes, it is important to know whether a genotype shows a response to additional $\mathrm{N}$ under drought. Reduced above ground growth (Fig. 2c), tuber $\mathrm{N}$ reserves, and $\mathrm{N}$ applied in the field were factors in optimization of available soil $\mathrm{N}$ to maintain tuber production (Baligar et al. 2001, Lahlou et al. 2003). Additional nitrogen reduced HI (Fig. 2b), underlining the importance of understanding the effect of $\mathrm{N}$ fertilization on a particular genotype to avoid fertilizing without achieving a yield gain.

The amount of residual $\mathrm{NO}_{3}{ }^{-}$in the soil increased more when the soil was dry, indicating the inability of 
Fig. 5 Chlorophyll content (SPAD units) (a, b, c and $\mathbf{d})$ and leaf area (e and $\mathbf{f})$ in three potato genotypes (UNICA, Achirana, and $307,077.16$ ) under two irrigation treatments and two $\mathrm{N}$ levels (D200 kg N.ha-

$1=$ Drought with $200 \mathrm{~kg} / \mathrm{ha}$ of N, D0N $=$ Drought with $0 \mathrm{~kg} / \mathrm{ha}$ of N, W200 kg N.ha-1 = Wellwatered plants with $200 \mathrm{~kg} / \mathrm{ha}$ of $\mathrm{N}$, and $\mathrm{W} 0 \mathrm{~N}=$ well-watered with $0 \mathrm{~kg} / \mathrm{ha}$ of N). Days after planting (DAP). Data are means $\pm \mathrm{SE}$
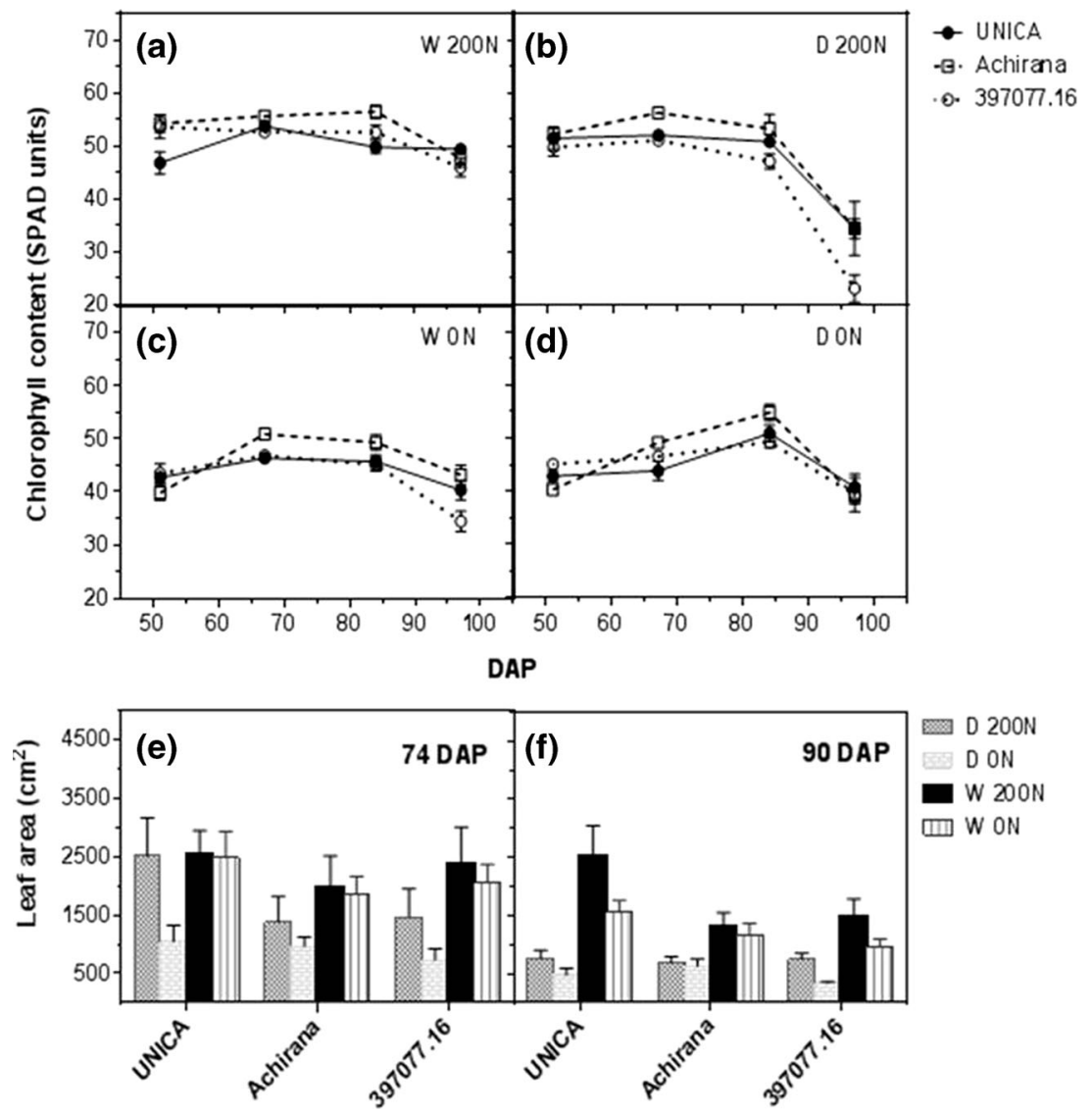

the crop to take up N, resulting in lower NUE (Fig. 3b). Drought limits the availability of $\mathrm{NO}_{3}{ }^{-}$by reducing its mobilization in soil-plant systems due to the increase in mineralization and decrease in denitrification (Waraich et al. 2011). Nitrate synergistically promotes absorption of cations such as $\mathrm{K}^{+}, \mathrm{Ca}^{+2}$ and $\mathrm{Mg}^{+2}$, which improves the nutrition of the crop (Fageria and Baligar 2005), and could be the reason for the increased DTI that we saw in our study (Fig. 3a).

Achirana-INTA had the lowest DTI, and was most affected by drought in terms of NUE (Fig. 3), although under WW conditions (WON) its NUE was superior compared to the other genotypes. There was also no recovery of DTI with $\mathrm{N}$ application in Achirana-INTA (Fig. 3a), as for yield and total biomass, probably because the NUE was the lowest of the three genotypes under drought, indicating that the plant could not use any $\mathrm{N}$ present. SPAD, CC and NDVI (Figs. 4 and 5), some of the physiological traits evaluated in this experiment, have been found to be good predictors of yield as well as good indicators of the $\mathrm{N}$ status of the plant, with strong and positive correlation among them and with yield (Sup. Table 2). NDVI has previously been reported to be moderately useful in predicting individual canopy properties such as photosynthetic rate, net carbon fixation, and plant transpiration, among others (Glenn et al. 2008, Boelman et al. 2003, Boelman et al. 2005). Our results also showed that these traits can be useful as early predictors of stress in crops, as the correlation coefficient of yield and NDVI have been found at different developmental stages, indicating that yield could be estimated well in advance of harvest (Aparicio et al. 2000, Serrano et al. 2000).

Overall, each genotype had different strategies to manage $\mathrm{N}$ and to cope with drought stress. Both UNICA and CIP397077.16 tolerated drought in terms of yield maintenance and used the $\mathrm{N}$ present in the soil more efficiently, also under drought, than Achirana-INTA. NDVI and SPAD values were both good indicators of early drought stress and the $\mathrm{N}$ status of the plant. Improved NUE and a greater understanding of the physiological response of crops to drought stress will help to reduce fertilizer use, lessening the effects of water contamination and lead to money savings for farmers.

Acknowledgments This experiment was financed by FONTAGRO, the SAGES project from the Canadian cooperation office and the Scientific and technical committee CGIAR. Authors thank Braulio La Torre for his support in the nitrate analysis and Napoleon Martinez for his assistance in field assessments. 
Open Access This article is distributed under the terms of the Creative Commons Attribution 4.0 International License (http:// creativecommons.org/licenses/by/4.0/), which permits unrestricted use, distribution, and reproduction in any medium, provided you give appropriate credit to the original author(s) and the source, provide a link to the Creative Commons license, and indicate if changes were made.

\section{References}

Ahmad, R., E.A. Waraich, M.Y. Ashraf, S. Ahmad, and T. Aziz. 2013. DOES NITROGEN FERTILIZATION ENHANCE DROUGHT TOLERANCE In SUNFLOWER? A REVIEW. Journal of Plant Nutrition 37: 942-963.

Anithakumari, A.M., K.N. Nataraja, R.G. Visser, and C.G. van der Linden. 2012. Genetic dissection of drought tolerance and recovery potential by quantitative trait locus mapping of a diploid potato population. Molecular Breeding 30: 1413-1429.

Aparicio, N., D. Villegas, J. Casadesus, J.L. Araus, and C. Royo. 2000. Spectral vegetation indices as nondestructive Tools for determining durum wheat yield. Agronomy Journal 92: 83-91.

Ashraf, M., M. Shabaz, and M.Y. Ashraf. 2001. Influence of nitrogen supply and Water stress on growth and nitrogen, phosphorus, potassium and calcium contents in Pearl Millet. Biologia Plantarum 44: 459-462.

Ayre O.E., Roman R. 1992. Métodos analíticos para suelos y tejido vegetal usados en el trópico húmedo. Serie didáctica. INIAA. Manual técnico 0.6/3.2 N4. Lima, Perú.

Bakr, E.M. 2005. A new software for measuring leaf area, and area damaged by Tetranychus urticae Koch. Journal of Applied Entomology 129(3): 173-175

Baligar, V.C., N.K. Fageria, and Z.L. He. 2001. NUTRIENT Use EFFICIENCY In PLANTS. Communications In Soil Science And Plant Analysis 32: 921-950.

Bélanger, G., J.R. Walsh, J.E. Richards, P.H. Milbum, and N. Ziadi. 2001. Tuber growth and biomass partitioning of two potato cultivars grown under different $\mathrm{n}$ fertilization rates with and without irrigation. American Journal of Potato Research 78: 109-117.

Boelman, N., M. Stieglitz, H. Rueth, M. Sommerkorn, K. Griffin, G. Shaver, and J. Gamon. 2003. Response of NDVI, biomass, and ecosystem gas exchange to long-term warming and fertilization in wet sedge tundra. Oecologia 135: 414-421.

Boelman, N., M. Stieglitz, K. Griffin, and G. Shaver. 2005. Inter-annual variability of NDVI in response to long-term warming and fertilization in wet sedge and tussock tundra. Oecologia 143: 588-597.

Cabello, R., P. Monneveux, F. De Mendiburu, and M. Bonierbale. 2013. Comparison of yield based drought tolerance indices in improved varieties, genetic stocks and landraces of potato (Solanum tuberosum L.). Euphytica 193: 147-156.

Costa, L., G. Vedove, G. Gianquinto, R. Giovanardi, and A. Peressotti. 1997. Yield, water use efficiency and nitrogen uptake in potato: influence of drought stress. Potato Research 40: 19-34.

Deblonde, P.M.K., and J.F. Ledent. 2001. Effects of moderate drought conditions on green leaf number, stem height, leaf length and tuber yield of potato cultivars. European Journal of Agronomy 14: 31-41.

Dell, E.A., D.S. Carley, T. Rufty, and W. Shi. 2012. Heat stress and N fertilization affect soil microbial and enzyme activities in the creeping bentgrass (Agrostis stolonifera L.) rhizosphere. Applied Soil Ecology 56(2012): 19-26.

Devaux A., Ordinola M.E., Hibon A. \& Flores F.A. 2010. El sector papa en la región andina: Diagnóstico y elementos para una visión estratégica (Bolivia, Ecuador y Perú). In: (CIP), I. P. C. (Ed.).

Fageria N.K. \& Baligar V.C. 2005. Enhancing Nitrogen Use Efficiency in Crop Plants. In: DONALD, L. S. (Ed.) Advances in Agronomy. Academic Press.
FAO. 2011. FAOSTAT Database. Available at http://faostat.fao.org/.

Glenn E.P., Huete A.R., Nagler P.L. \& Nelson S.G. 2008. Relationship Between Remotely-sensed Vegetation Indices, Canopy Attributes and Plant Physiological Processes: What Vegetation Indices Can and Cannot Tell Us About the Landscape. Sensors (Basel, Switzerland), 8: 2136-2160.

He, M., and F.A. Dijkstra. 2014. Drought effect on plant nitrogen and phosphorus: a meta-analysis. New Phytologist 204: 924-931.

Hirel, B., J. Le Gouis, B. Ney, and A. Gallais. 2007. The challenge of improving nitrogen use efficiency in crop plants: towards a more central role for genetic variability and quantitative genetics within integrated approaches. Journal of Experimental Botany 58(9): 2369-2387.

IPCC. 2007. Climate change 2007. the physical science basis. contribution of Working Group I to the 4th assessment report of the International panel on climate change. In Cambridge, eds. S. SOLOMON, D. QIN, M. MANNING, Z. CHEN, M. MARQUIS, K.B. AVERYT, et al. New York, USA: Cambridge University Press.

Lahlou, O., S. Ouattar, and J.F. Ledent. 2003. The effect of drought and cultivar on growth parameters, yield and yield components of potato. Agronomie 23: 257-268.

Levallois, P., M. Theriault, J. Rouffignat, S. Tessier, R. Landry, P. Ayotte, M. Girard, S. Gingras, D. Gauvin, and C. Chiasson. 1998. Groundwater contamination by nitrates associated with intensive potato culture in Quebec. Science of the Total Environment 217: 91-101.

Levy, D., W.K. Coleman, and R.E. Veilleux. 2013. Adaptation of potato to Water shortage: Irrigation Management and Enhancement of tolerance to drought and salinity. American Journal of Potato Research 90: 186-206.

Li, L., Y.L. Qin, Y.C. Liu, Y.C. Hu, and M.S. Fan. 2012. Leaf Positions of potato suitable for determination of nitrogen Content with a SPAD meter. Plant Production Science 15: 317-322.

Olesen, J.E., M. Trnka, K.C. Kersebaum, A.O. Skjelvag, B. Seguin, P. Peltonen-Sainio, F. Rossi, J. Kozyra, and F. Micale. 2011. Impacts and adaptation of european crop production systems to climate change. European Journal of Agronomy 34: 96-112.

Payne, W.A., L.R. Hossner, A.B. Onken, and C.W. Wendt. 1995. Nitrogen and phosphorus uptake in Pearl Millet and its relation to nutrient and transpiration efficiency. Agronomy Journal 87: 425-431.

Piao, S., P. Ciais, Y. Huang, Z. Shen, S. Peng, J. Li, L. Zhou, H. Liu, Y. Ma, Y. Ding, P. Friedlingstein, C. Liu, K. Tan, Y. Yu, T. Zhang, and J. Fang. 2010. The impacts of climate change on water resources and agriculture in China. Nature 467: 43-51.

Raun, W.R., and G.V. Johnson. 1999. Improving nitrogen use efficiency for cereal production. Agronomy Journal 91: 357-363.

Schafleitner, R., R. Gutierrez, R. Espino, A. Gaudin, J. Pérez, M. Martínez, A. Domínguez, L. Tincopa, C. Alvarado, G. Numberto, and M. Bonierbale. 2007. Field screening for variation of drought tolerance in Solanum tuberosum L. by agronomical, physiological and genetic analysis. Potato Research 50: 71-85.

Serrano, L., I. Filella, and J. Penuelas. 2000. Remote sensing of biomass and yield of Winter Wheat under different nitrogen supplies. Crop Science 40: 723-731.

Vos, J., and M. Bom. 1993. Hand-held chlorophyll meter - a promising tool to assess the nitrogen status of potato foliage. Potato Research 36: 301-308.

Waraich, E.A., Rashid Ahmad, Saifullah, M.Y. Ashraf, and Ehsanullah. 2011. Role of mineral nutrition in alleviation of drought stress in plants. Australian Journal of Crop Science 5: 764-777.

Wu, J.D., D. Wang, C.J. Rosen, and M.E. Bauer. 2007. Comparison of petiole nitrate concentrations, SPAD chlorophyll readings, and QuickBird satellite imagery in detecting nitrogen status of potato canopies. Field Crops Research 101: 96-103.

Xu, G., X. Fan, and A.J. Miller. 2012. Plant nitrogen assimilation and use efficiency. Annual Review of Plant Biology 63: 153-182. 